\title{
New records of Uromyces erythronii (Pucciniales) from Ukraine
}

\author{
Yuri Ya. TYKHONENKO ${ }^{1}$, Nadiya N. SYTSCHAK ${ }^{2}$, Alexander A. KAGALO², Oleksandr O. ORLOV \\ ${ }^{1}$ M.G. Kholodny Institute of Botany, National Academy of Sciences of Ukraine \\ 2, Tereshchenkivska Str., Kyiv 01004, Ukraine \\ yu.ya.tykhonenko@gmail.com \\ ${ }^{2}$ Institute of Ecology of the Carpathians, National Academy of Sciences of Ukraine \\ 4, Kozelnytska Str., Lviv 79026, Ukraine \\ sytschak@ukr.net \\ kagalo@mail.lviv.ua \\ ${ }^{3}$ G.M.Vysotsky Polisskiy Branch of URIFFM \\ 2, Neskorenykh Str., Dovzhyk village, Zhytomyr District, Zhytomyr Region 10004, Ukraine \\ orlov.botany@gmail.com
}

Tykhonenko Yu.Ya., Sytschak N.N., Kagalo A.A., Orlov O.O. New records of Uromyces erythronii (Pucciniales) from Ukraine. Ukr. Bot. J., 2017, 74(2): 184-188.

Abstract. Specimens of the rust fungus Uromyces erythronii were recorded on Erythronium dens-canis, a rare species listed in the Red Data Book of Ukraine, in April 2016 near Chemeryntsi village (Lviv Region, Ukraine) and in May 2016 near Zaluzhne village (Zhytomyr Region, Ukraine). An investigation of the Erythronium specimens deposited in the herbaria of vascular plants of Lviv Natural History Museum (LWS) and M.G. Kholodny Institute of Botany $(K W)$ revealed four more samples of this fungus. A list of all localities in which $U$. erythronii was recorded in Ukraine is provided. The article is illustrated by micrographs obtained by scanning electron microscopy.

Keywords: Erythronium dens-canis, rust fungi, distribution, morphology

\section{Introduction}

The genus Erythronium L. comprises about 30 species of spring-flowering perennial plants distributed in temperate regions of the Northern Hemisphere. It was established that the genus is probably sister to Amana Honda and that Tulipa L. is sister to the clade of Erythronium and Amana (Clennett et al., 2012). Within Erythronium, there are three strongly supported geographically distinct clades occurring in Eurasia, western North America, and eastern North America (Allen et al., 2003; Clennett et al., 2012). Its centre of diversity lies in Oregon and northern California (Allen et al., 2003). The geographic distribution of the only European species $E$. dens-canis L. is highly disjunct. There are several fragmented areas, clearly separated from one another: north-eastern Portugal, northern

(C) Yu.Ya. TYKHONENKO, N.N. SYTSCHAK, A.A. KAGALO, O.O. ORLOV, 2017
Spain and the Pyrenees, the Massif Central and the western Alps, northern Italy, Hungary and the Balkans to northern Greece (Kleih, 2010). Isolated populations north of the Alps are located in the Czech Republic, Slovakia (Fischer et al., 2008), and Ukraine (Chervona knyha..., 2009).

Uromyces erythronii (DC.) Pass. parasitizes Eurasian species of Erythronium. In Japan and China it was also recorded on representatives of Amana (Hiratsuka et al., 1992; Teng, 1996), which is in concordance with the modern status of Amana as a genus separate from Tulipa and closely related to Erythronium. It should be noted that rusts of the genus Uromyces (Link) Unger do not occur on plants of the genus Tulipa. The earlier mentions of this fungus in Ukraine (Zerova et al., 1971; Tykhonenko, 1999) are based on the only collection from Transcarpathian Region, which, unfortunately, has been lost. 
The aim of this publication is to report new records of U. erythronii made in Ukraine in 2016 as well as those identified from the previously collected herbarium specimens of its host plant.

\section{Materials and Methods}

Specimens collected in the field were labelled and dried for further treatment. Aeciospores and teliospores mounted in water and/or lactic acid were investigated by light microscopy under Primo Star microscope and AxioVision 4.7 software, used as well for measurements of microstructures. For scanning electron microscopy samples were coated with an ultrathin coating of gold by ion beam sputtering unit JFC-1100. Images were obtained by scanning electron microscope JEOL JSM6060 LA. Analysis of general distribution is based on the data from many bibliographic sources, and databases available through the Internet.

The specimens are deposited in the Mycological Herbarium of M.G. Kholodny Institute of Botany, National Academy of Sciences of Ukraine $(K W)$ and in the herbarium of the Institute of Ecology of the Carpathians, National Academy of Sciences of Ukraine $(L W K S)$.

\section{Results and Discussion}

The rust fungus Uromyces erythronii was recorded on Erythronium dens-canis, a rare species listed in the Red Data Book of Ukraine. Specimens were collected in April 2016 near Chemeryntsi village (Lviv Region, Ukraine) and in May 2016 near Zaluzhne village (Zhytomyr Region, Ukraine). Subsequent investigation of the Erythronium specimens stored in the herbaria of vascular plants of Lviv Natural History Museum $(L W S)$ and M.G. Kholodny Institute of Botany $(K W)$ revealed four more samples of this fungus. The synonymic names, description of spermogonial, aecial and telial stages, and data on distribution in Ukraine of this species are provided below. Original illustrations are followed by information on its morphology, general distribution and phenology.

Uromyces erythronii (DC.) Pass., Comm. Soc. crittog. Ital. 2(fasc. 3): 452 (1867). - Aecidium erythronii DC., in Lamarck \& de Candolle, Fl. franç., Edn 3 (Paris) 2: 246 (1805). - Caeoma cynophron Schltdl., Linnaea 1: 242 (1826). - Caeoma erythroniatum Link, in Willdenow, Sp. pl., Edn 4 6(2): 42 (1825). - Coeomurus erythronii (DC.) Kuntze [as 'Caeomurus'], Revis. gen. pl. (Leipzig) 3(2): 450 (1898). - Uredo erythronii DC., in de Candolle \& Lamarck, Fl. franç., Edn 3 (Paris) 5/6: 67 (1815).

Spermogonia on both sides of leaves, honeycoloured, solitary or mixed with the aecia, more or less conical. Aecia mostly hypophyllous, although they may appear on the petioles, in oblong or orbicular groups on yellow spots, generally quite conspicuous, peridium $0.3-0.4 \mathrm{~mm}$ in diameter, at first covered by the epidermis but later cup-shaped with coarsely incised and outwardly turned margin (Figure, $a$ ). Peridial cells are of variable shape, generally pentagonal, rhomboid or almost square, outer wall almost smooth, inner is covered with warts. Aeciospores globose, polygonal or ellipsoidal, $20-30 \times 15-24 \mu \mathrm{m}$, densely and finely verruculose (Figure, $b, c$ ), with a yellow-orange content. Telia on both sides of leaves in groups, rounded or elongated, 0.3-1 mm long, pulverulant (Figure, $d$ ), chocolate-brown. Teliospores globoid or ovoid, 22$42 \times 15-25 \mu \mathrm{m}$, with prominent apical papilla, wall is ornamented with longitudinally, sometimes bifurcated, ridges which are transversely connected by short, thin and almost parallel striae (Figure, $e, f$ ), pedicel is short and hyaline.

0, I, III - on Erythronium and Amana species.

Distribution in Ukraine*:

On Erythronium dens-canis

0, I - Lviv Region, Peremyshlyany District, Chemeryntsi village, Golyj Kinets hamlet, Mokre wood, forest of Fagus sylvatica L. and Carpinus betulus L., 49 40' N, 24 44' E, 24.04.1935, leg. F. Fotyniuk ( $L W S$ 21164, $L W K S-B$ 1192, $K W$-M 70319); ibid., 08.04.2016, leg. A. Kagalo and N. Sytschak (LWS 31781, LWKS-B 1191, KW-M 70320). Transcarpathian

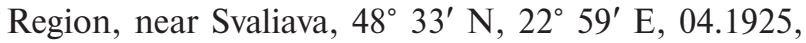
leg. A. Margitai ( $K W 122870)$; Tiachiv District, Velyka Uholka village, near road to the tract Aldomyrove, forest of Fagus sylvatica, $48^{\circ} 15^{\prime} \mathrm{N}, 23^{\circ} 40^{\prime} \mathrm{E}, 22.04 .1975$, leg. L. Tasenkevych (LWS 21149, KW-M 70321).

III - Zhytomyr Region, Romaniv District, $2 \mathrm{~km}$ to the west of Zaluzhne village, forest of Quercus robur L. and Carpinus betulus, 50 $14^{\prime} \mathrm{N}, 27^{\circ} 56^{\prime} \mathrm{E}$, 12.05.2016, leg. O. Orlov ( $K W-M$ 70322). Lviv Region, Peremyshlyany District, Chemeryntsi village, Golyj Kinets hamlet, Mokre wood, forest of Fagus sylvatica

* In spring of the current year aecial stage of $U$. erythronii was collected in a new locality: Transcarpathian Region, Rakhiv District, $4.6 \mathrm{~km}$ to the east of Luh village, Carpathian Biosphere Reserve, Kuziy massif, hornbeam-sessile-oakbeech forest on the eastern slope of Tempa Mt., $47^{\circ} 57^{\prime} \mathrm{N}, 24^{\circ}$ 07' E, 06.04.2017, leg. N. Sytschak and A. Kagalo. 


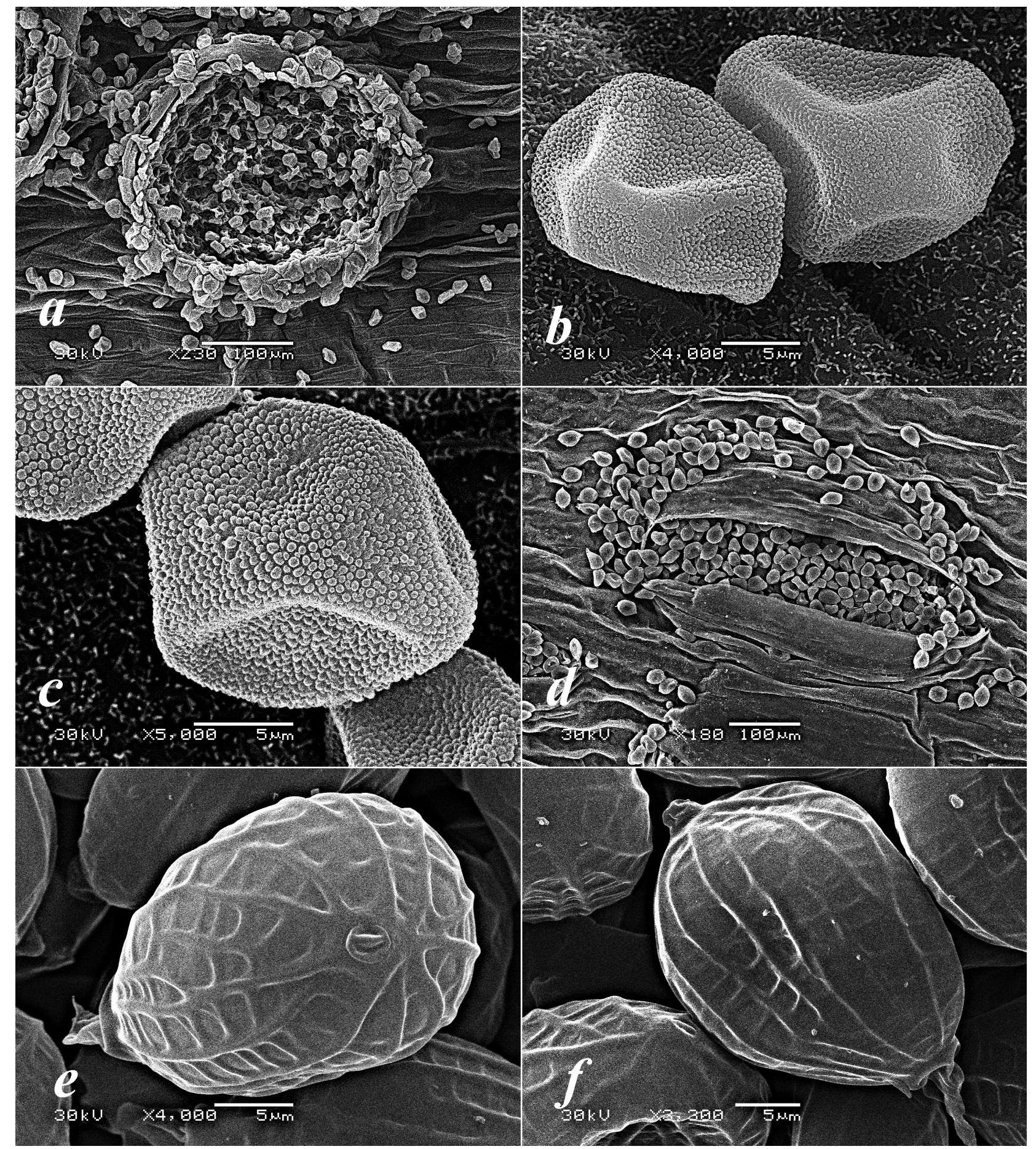

Uromyces erythronii on Erythronium dens-canis: $a$ - aecium; $b, c$ - aeciospores; $d$ - telium; $e, f$ - teliospores. Scale bars: $a, d-$ $100 \mu \mathrm{m} ; b, c, e, f-5 \mu \mathrm{m}$ 
and $C$. betulus, $49^{\circ} 40^{\prime} \mathrm{N}, 24^{\circ} 44^{\prime} \mathrm{E}, 09.05 .1934$, leg. F. Fotyniuk ( $L W S 21143, K W-M 70323$ ).

General distribution. Europe: Austria, Bulgaria, Croatia, Czech Republic, France, Hungary, Italy, Montenegro, Romania, Slovakia, Slovenia, Spain, Switzerland, Ukraine. Asia: China, Georgia, Japan, Korea, Russian Federation (Southern Siberia). Dogtooth violets are widely cultivated in public and private gardens beyond the natural ranges of Erythronium species; therefore, U. erythronii has been also recorded in Belgium (Vanderweyen, Fraiture, 2008), Germany (Kruse et al., 2013), and the UK (Wilson, Henderson, 1966; Henderson, 2000).

Uromyces erythronii is absent from North America despite of presence of about 20 indigenous species of Erythronium. The only rust recorded on representatives of Erythronium in this continent is $U$. heterodermus Syd. \& P. Syd. distributed in the western USA and Canada, which is quite different from $U$. erythronii by its morphology: it lacks aecia in its life cycle, and its teliospores are striately verrucose above and almost smooth below (Arthur, 1934). It implies that $U$. erythronii probably originated after the divergence of Eurasian and eastern North American clades of Erythronium but before the split of Eurasian species.

Uromyces erythronii is a typical spring species strictly dependant on phenology of its host plant. According to the special study (Fukuda, Nakamura, 1987), teliospores germinate in the soil and basidiospores infect the tightly rolled leaves at the early period of the growing season. Aecia appear about one week after the leaf emergence. Telia are produced by stomatal infection of aeciospores when aerial shoots began to yellow and after they have completely decayed, teliospores disperse to the ground. The growth period of both host and parasite lasts only for about a month. All four Ukrainian specimens of $U$. erythronii with aecial stage were collected in April and both with telia - in the first half of May.

\section{Acknowledgements}

We are grateful to V.I. Sapsay from the staff of the M.G. Kholodny Institute of Botany NASUfor his assistance in scanning electron microscopy of Uromyces erythronii.

\section{REFERENCES}

Allen G.A., Soltis D.E., Soltis P.S. Phylogeny and biogeography of Erythronium (Liliaceae) inferred from chloroplast $m a t K$ and nuclear rDNA ITS sequences. Syst. Botany, 2003, 28(3): 512-523. doi: 10.1043/02-18.1

Arthur J.C. Manual of the rusts of United States and Canada, Lafayette, Indiana: Pardue Res. Found., 1934, 438 pp.

Chervona knyha Ukrainy. Roslynnyi svit (Red Data Book of Ukraine. Vegetable Kingdom). Ed. Ya.P. Didukh, Kyiv: Globalkonsaltyng, 2009, 912 pp. [Червона книга Украйни. Рослинний світ. Ред. Я.П. Дідух, Київ: Глобалконсалтинг, 2009, 912 с.].

Clennett J.C.B., Chase M.W., Forest F., Olivier Maurin O., Wilkin P. Phylogenetic systematics of Erythronium (Liliaceae): morphological and molecular analyses. Bot. J. Linn. Soc., 2012, 170(4): 504-528. doi: 10.1111/j.1095-8339.2012.01302.x

Fischer M.A., Oswald K., Adler W. Exkursionsflora für Österreich, Liechtenstein und Südtirol. 3. Aufl., Linz: Biologiezentrum der Oberösterreichischen Landesmuseen, 2008, 1392 S.

Fukuda T., Nakamura S. Biotic interaction between a rust fungus, Uromyces erythronii Pass., and its host plant, Erythronium japonicum Decne. (Liliaceae). Plant Spec. Biol., 1987, 2: 75-83. doi: 10.1111/j.1442-1984.1987.tb00034.x

Henderson D.M. A Checklist of the Rust Fungi of the British Isles, Surrey: Brit. Mycol. Soc., 2000, 36 pp.

Hiratsuka N., Sato S., Katsuya K., Kakishima M., Hiratsuka Y., Kaneko S., Ono Y., Sato T., Harada Y., Hiratsuka T., Nakayama K. The rust flora of Japan, Tsukuba-shi, Ibaraki: Tsukuba Shuppankai, 1992, $1205 \mathrm{pp}$.

Kleih M. Cartografia floristica: distribuzione di Erythronium dens-canis nell'Italia settentrionale e nelle regioni confinanti. Inform. Bot. Ital., 2010, 42(1): 177-182.

Kruse J., Kummer V., Thiel H. Noteworthy records of phytopathogenic micromycetes (3). Z. Mykol., 2013, 80(2): 593-626.

Teng S.C. Fungi of China, Ithaca: Mycotaxon Ltd., 1996, $586 \mathrm{pp}$.

Tykhonenko Yu.Ya. Genus Uromyces Unger (Uredinales) in Ukraine. Ukr. Bot. J., 1999, 56(5): 484-490.

Vanderweyen A., Fraiture A. Catalogue des Uredinales de Belgique, $2^{\text {ème }}$ partie, Pucciniaceae (sauf Puccinia). Lejeunia. Nouv. sér., 2008, 185: 1-31.

Wilson M., Henderson D.M. British rust fungi, London: Cambridge Univ. Press, 1966, 384 pp.

Zerova M.Ya., Morochkovskyi S.F., Radziyevskyi H.H., Smitska M.F. Vyznachnyk hrybiv Ukrainy. Bazydiomitsety: Dakrymitsetalni, Tremelalni, Aurykularialni, Sazhkovydni, Irzhasti (Handbook of the fungi of Ukraine. Basidiomycetes: Dacrymycetales, Tremellales, Auriculariales, Ustilaginales, Uredinales), Kyiv: Naukova Dumka, 1971, vol. 4, 316 pp. [Зерова М.Я., Морочковський С.Ф., Радзієвський Г.Г., Сміцька М.Ф. Визначник грибів України. Базидіоміцети: Дакриміцетальні, Тремелальні, Аурикуларіальні, Сажкковидні, Іржасті, Київ: Наук. думка, 1971, т. 4, 316 с.].

Recommended for publication by $\quad$ Submitted 08.02.2017 V.P. Hayova 
Тихоненко Ю.Я. ${ }^{1}$, Сичак Н.М. ${ }^{2}$, Кагало О.О. ${ }^{2}$, Орлов О.О. ${ }^{3}$ Нові знахідки Uromyces erythronii

(Pucciniales) з України. Укр. бот. журн., 2017, 74(2): 184-188.

${ }^{1}$ Інститут ботаніки ім. М.Г. Холодного НАН України вул. Терещенківська, 2, Київ 01004, Україна

${ }^{2}$ Інститут екології Карпат НАН України

вул. Козельницька, 4, Львів 79026, Україна

${ }^{3}$ Поліський філіал УкрНДІЛГА ім. Г.М. Висоцького вул. Нескорених, 2, с. Довжик, Житомирський р-н, Житомирська обл. 10004, Україна

У квітні 2016 р. поблизу с. Чемеринці (Львівська обл.), а у травні 2016 р. поблизу с. Залужне (Житомирська обл.) були зібрані зразки гриба Uromyces erythronii на Erythronium dens-canis - рідкісній рослині, внесеній до Червоної книги України. У результаті дослідження зразків Erythronium, які зберігаються у гербаріях судинних рослин Львівського природознавчого музею $(L W S)$ та Інституту ботаніки ім. М.Г. Холодного $(K W)$, було виявлено ще чотири випадки розвитку цього гриба. У статті наведено список усіх локалітетів, в яких U. erythronii був зареєстрований в Україні. Робота ілюстрована мікрофотографіями, отриманими за допомогою сканувального електронного мікроскопа.

Ключові слова: Erythronium dens-canis, іржасті гриби, поширення, морфологія
Тихоненко Ю.Я. ${ }^{1}$, Сычак Н.Н. ${ }^{2}$, Кагало А.А. ${ }^{2}$, Орлов А.А. ${ }^{3}$ Новые находки Uromyces erythronii (Pucciniales) из Украины. Укр. бот. журн., 2017, 74(2): $184-188$.

${ }^{1}$ Институт ботаники им. Н.Г. Холодного НАН Украины ул. Терещенковская, 2, Киев 01004, Украина

${ }^{2}$ Институт экологии Карпат НАН Украины ул. Козельницкая, 4, Львов 79026, Украина

${ }^{3}$ Полесский филиал УкрНИИЛХА им. Г.Н. Высоцкого ул. Нескореных, 2, с. Довжик, Житомирский р-н, Житомирская обл. 10004, Украина

В апреле 2016 г. в окрестностях с. Чемеринцы (Львовская обл.), а в мае 2016 г. в окрестностях с. Залужное (Житомирская обл.) были собраны образцы гриба Uromyces erythronii на Erythronium dens-canis - редком растении, занесенном в Красную книгу Украины. В результате исследования образцов Erythronium, хранящихся в гербариях сосудистых растений Львовского природоведческого музея $(L W S)$ и Института ботаники им. Н.Г. Холодного $(K W)$, было выявлено еще четыре случая развития этого гриба. В статье приведен список всех локалитетов, в которых U. erythronii был зарегистрирован в Украине. Работа иллюстрирована микрофотографиями, полученными с помощью сканирующего электронного микроскопа.

Ключевые слова: Erythronium dens-canis, ржавчинные грибы, распространение, морфология 